\title{
Karakterisasi Fenotip dan Kekerabatan Varietas Jagung Lokal Kabupaten Timor Tengah Utara
}

\author{
Polikarpia Wilhelmina Bani ${ }^{\text {a }}$ \\ ${ }^{a}$ Fakultas Pertanian, Universitas Timor, Kefamenanu, TTU - NTT, Indonesia.
}

\section{Article Info}

\section{Article history:}

Received 8 Februari 2018

Received in revised form 19 Maret 2018

Accepted 4 Juli 2018

DOI:

https://doi.org/10.32938/sc.v3i03.318

\section{Keywords:}

Karakterisasi Fenotip

Kekerabatan

Jagung Lokal

\section{Abstrak}

Sebagian besar masyarakat TTU masih bergantung pada hasil pertanian setempat. Salah satu tanaman pertanian yang serin dibudidayakan adalah jagung lokal. Jagung lokal memiliki manfaat yang beragam, mulai dari sumber pangan alternatif, pakan ternak, hingga produksi bio-etanol yang akhir-akhir ini menjadi isu global dan kajian sains. Informasi mengenai karakter fenotip tanaman sangat penting dalam program pemuliaan tanaman. Penelitian ini bertujuan untuk mengkarakterisasi fenotip dan kekerabatan varietas jagung lokal Kabupaten Timor Tengah Utara. Varietas jagung lokal Kabupaten Timor Tengah Utara yang digunakan dalam penelitian ini yaitu 'pena molo', 'pena fatu', 'pena kikis', dan 'pena boto'. Sebanyak 14 karakter fenotip diamati untuk menilai variasi genetik berdasarkan karakter fenotip. Pengukuran karakter fenotip didasarkan pada sifat-sifat kualitatif dan kuantitatif. Data fenotip selanjutnya diolah dengan program Multi Variate Statistical Package (MVSP) dengan metode UPGMA (Unweighted Pair-Group Method with Arithmetic Average) dan Gower General Macthing Coefficient untuk mengkonstruksi dendogram. Hasil penelitian menunjukkan koefisien kemiripan berdasarkan karakter fenotip adalah $0,43 \%-1 \%$.

\section{Pendahuluan}

Kabupaten Timor Tengah Utara (TTU) merupakan salah satu kabupaten yang terletak di Provinsi Nusa Tenggara Timur (NTT). Sebagian besar masyarakat TTU masih bergantung pada hasil pertanian setempat. Salah satu tanaman pertanian yang sering dibudidayakan adalah jagung lokal. Jagung lokal memiliki manfaat yang beragam, mulai dari sumber pangan alternatif, pakan ternak, hingga produksi bio-etanol yang akhir-akhir ini menjadi isu global dan kajian sains. Peningkatan kemanfaatan jagung mendorong perkembangan pertanian jagung di Kabupaten TTU. Daerah penghasil jagung di Kabupaten TTU didominasi oleh Kecamatan Insana, Kecamatan Noemuti, Miomafo Timur, dan Miomafo Barat (Badan Pusat Statistik Kabupaten Timor Tengah Utara, 2013).

Kebutuhan akan jagung lokal semakin bertambah seiring dengan meningkatnya pertumbuhan penduduk dan perkembangan industri pakan dan pangan. Namun, produksi jagung lokal masih rendah dan hanya cukup untuk kebutuhan rumah tangga.

Program pemuliaan tanaman merupakan salah satu faktor penting dalam peningkatan produktivitas tanaman. Salah satu kendala program pemuliaan tanaman adalah kurang informasi tentang karakter fenotip. Informasi tentang karakter fenotip varietas jagung lokal sangat dibutuhkan dalam menentukan sifat unggul yang berguna untuk meningkatkan produktivitas jagung. Hal ini tentu akan berpengaruh terhadap produksi berbagai varietas jagung bersifat khusus misalnya jagung protein mutu tinggi, jagung manis, jagung pulut, jagung biomassa tinggi, dan jagung genjah. Identifikasi menggunakan ciri morfologi yang dalam hal ini karakter fenotip banyak digunakan dalam determinasi dan identifikasi variasi atau keragaman tanaman karena mudah dilakukan dan dapat diamati secara langsung (Mustofa $d k k$., 2013).

Keanekaragaman varietas fenotip jagung lokal di Kabupaten TTU berpotensi menjadi sumber karakter-karakter unggulan guna mengatasi berbagai kendala dalam budidaya jagung di Kabupaten TTU bahkan Indonesia. Informasi hubungan kekerabatan di antara materi pemuliaan berperan penting dalam pemilihan tetua secara efisien melalui program pemuliaan tanaman (Pabendon $d k k$., 2007). Materi pemuliaan yang berkerabat jauh dibutuhkan dalam menentukan tetua persilangan untuk merakit varietas yang diinginkan. Persilangan antara tetua yang berkerabat jauh akan menghasilkan keturunan yang mempunyai segregasi luas, sehingga memudahkan dalam memilih varietas yang diinginkan (Amzeri $d k k$., 2011).

Pemuliaan tanaman merupakan suatu metode eksploitasi potensi genetik tanaman untuk mendapatkan kultivar atau varietas budidaya baru yang berkualitas tinggi pada kondisi lingkungan tertentu. Pendekatan pemuliaan tanaman secara konvensional dengan mengamati karakter fenotip yang dipilih dalam penelitian ini karena dapat langsung diamati serta tidak membutuhkan banyak biaya. Ketersediaan data varietas jagung lokal dan karakter fenotip jagung lokal sangat penting dan dibutuhkan selain untuk program pemuliaan tanaman juga untuk database bagi instansi terkait serta masyarakat dan peneliti yang menggunakan varietas jagung lokal untuk kebutuhan konsumtif dan penelitian (Fatmawati $d k k$., 2017)

Penelitian ini bertujuan untuk mengkarakterisasi fenotip dan melihat kekerabatan varietas jagung lokal di Kabupaten Timor Tengah Utara.

\section{Metode}

Penelitian ini dilaksanakan di lahan perkebunan masyarakat Naen Kefamenanu pada bulan Agustus sampai November 2016. Luas lahan penelitian yang digunakan adalah $100 \mathrm{~m}^{2}$ dengan ukuran setiap unit penanaman $5 \mathrm{~m}^{2} \times 1,5 \mathrm{~m}^{2}$. Setiap blok terdiri dari 50 pohon varietas jagung lokal Kabupaten TTU. Varietas jagung lokal yang di tanam adalah 'pena molo', 'pena fatu', 'pena kikis', dan 'pena boto'. Pemberian air dilakukan secara teratur mulai pada saat tanam sampai panen. Aplikasi pupuk dilakukan dua kali yaitu pada 7 hari setelah tanam dan 28-30 hari setelah tanam. Komposisi pupuk yang digunakan adalah Phonska, Urea, ZA $=30,200,100 \mathrm{~kg} / \mathrm{ha}$ berturut-turut.

Karakterisasi fenotip dilakukan pada saat jagung telah mencapai masa masak fisiologi. Hasil pengamatan terhadap 14 karakter fenotip varietas jagung lokal Kabupaten TTU merupakan data awal. Data selanjutnya dibuat dalam data multistate dengan memberi angka 0,1,2,3,4 sesuai petunjuk IPBGR 1991. Kemudian dianalisis dengan Multi Variate Statistical Package (MVSP) dengan metode UPGMA (Unweighted Pair-Group Method with Arithmetic Average) dan Gower General Similarity Coefficient sehingga dihasilkan diagram fenetik atau dendogram similaritas berdasarkan karakter fenotip 4 varietas jagung lokal Kabupaten TTU (Romesburg, 2004).

Karakter fenotip yang diamati adalah tinggi tanaman, tinggi letak tongkol, diameter batang, panjang daun, lebar daun, jumlah daun, waktu berbunga, jumlah percabangan malai, panjang tongkol tanpa kelobot, diameter tongkol tanpa kelobot, berat tongkol tanpa kelobot, jumlah biji per baris, jumlah baris biji per tongkol, dan berat 100 biji per tongkol. Teknik pengambilan data berdasarkan aturan pada International Board for Plant Genetic Resources (IBPGR, 1991).

\section{Hasil dan Pembahasan}

Berdasarkan karakter fenotip, varietas jagung lokal dalam penelitian ini menunjukkan keanekaragaman pada karakter habitus, daun, batang, malai dan tongkol (Tabel 1). Perbedaan tersebut dipengaruhi oleh faktor genetik dan faktor lingkungan (Maemunah \& Yusran, 2011)

Tabel 1. Karakter fenotip varietas jagung lokal Kabupaten TTU

\begin{tabular}{|c|c|c|c|c|}
\hline \multirow{2}{*}{$\begin{array}{c}\text { Karakter } \\
\text { Fenotip }\end{array}$} & \multicolumn{4}{|c|}{ Varietas Jagung Lokal } \\
\hline & Pena Molo & Pena Fatu & Pena Boto & Pena Kikis \\
\hline TT $(\mathrm{cm})$ & 129,4 (pendek) & 188,3 (sedang) & 177,5 (sedang) & 185,1 (seda \\
\hline TLT & 56,6 (sedang) & ggi) & 89,8 (tinggi) & \\
\hline JD (helai) & 9 (sedikit) & 12 (sedikit) & 11 (sedikit) & 11 (sedil \\
\hline $\mathrm{PD}(\mathrm{c}$ & 66,9 (sedang) & 92 (panjang) & 77,8 (panjang) & 89,1 (panjar \\
\hline LD $(c$ & $7,7(\mathrm{~s}$ & 7,5 $(\mathrm{s}$ & 8,05 & 0 \\
\hline DB $(\mathrm{cm})$ & 3,74 (besar) & 4,32 (besar) & 4,25 (besar) & bes \\
\hline WB (hst) & $\begin{array}{r}35 \text { (sangat } \\
\text { genjah) }\end{array}$ & 49 (sedang) & 45 (genjah) & en \\
\hline JPM & 16,1 (banyak) & $14,9(\mathrm{~s}$ & 14,2 & edal \\
\hline DT $(\mathrm{c}$ & $6,27(\mathrm{~s}$ & 4,9 & 4,9 & 6,8 \\
\hline BT ( & $79,5($ & in) & 49,8 & 60,2 \\
\hline PT $(\mathrm{cm})$ & $15(\mathrm{se}$ & 19,65 (panjang) & 15,63 (panjang) & 13,11 \\
\hline JBJ & 20 (banyak) & 12 (sedang) & 15 (sedang) & 10 (sedar \\
\hline JBR & 13 (sedang) & likit) & 9 (sedikit) & 11 (sedar \\
\hline BBJ (gr) & 28,09 (ringan) & 28,81 (ringan) & 22,72 & 32,14 (sedan \\
\hline ter & . & TIT & & 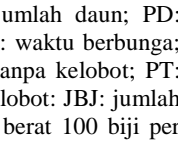 \\
\hline
\end{tabular}

Koefisien kemiripan antar individu dalam populasi jagung lokal (Tabel 2) berkisar antara 39,3 - 96,4\% dengan rata-rata 58,3. Menurut Rohlf \& NTSYS-p (2000), derajat kemiripan antar genotipe menggunakan matriks genetik dapat dibagi dalam 4 kategori yaitu kemiripan sangat dekat (sangat baik) $\mathrm{r}>0,9$; baik $0,8<\mathrm{r}<0,9$; kurang baik $0,7<\mathrm{r}<0,8$; buruk $\mathrm{r}<0,7$.

Tabel 2. Koefisien kemiripan dan matriks kekerabatan genetik jagung lokal Kabupaten TTU

\begin{tabular}{ccccc}
\hline Varietas & Pena Molo & Pena Fatu & Pena Boto & Pena Kikis \\
\hline Pena Molo & 1,000 & & & \\
Pena Fatu & 0,429 & 1,000 & & \\
Pena Boto & 0,464 & 0,964 & 1,000 & \\
Pena Kikis & 0,393 & 0,607 & 0,643 & 1,000 \\
\hline
\end{tabular}

Tingkat kemiripan genetik suatu populasi dapat digambarkan oleh jarak genetik dari individu-individu anggota populasi tersebut. Semakin kecil jarak 
genetik antar individu dalam suatu populasi, maka semakin seragam populasi tersebut. Sebaliknya semakin besar jarak genetik individu-individu di dalam suatu populasi, maka populasi tersebut mempunyai anggota yang semakin beragam (Subekti $d k k$., 2007).

\subsection{Karakteristik Persawahan dan Tanaman Padi Selama Periode Pengukuran}

Pengelompokkan berdasarkan karakter fenotip menghasilkan dendogram (Gambar 1) dengan koefisien kemiripan berkisar antara 0,40\%-1\%. Dendogram kemiripan genetik varietas jagung lokal menunjukkan bahwa pada kemiripan $62 \%$ populasi ini masih terbagi dalam 2 kelompok. Varietas jagung lokal 'Pena Fatu', 'Pena Boto' dan 'Pena Kikis' baru membentuk satu kelompok pada kemiripan 43\%. 'Pena kikis', 'Pena Boto' dan 'Pena Fatu' disatukan oleh 9 karakter fenotip yang sama membentuk kelompok 1 yaitu tinggi tanaman, tinggi letak tongkol, jumlah daun, panjang daun, lebar daun, diameter batang, jumlah percabangan malai, berat tongkol, dan jumlah biji per baris. Pena Molo memisah dan membentuk kelompok 2 karena dari 14 karakter fenotip tidak bersatu dengan kelompok

Walaupun keanekaragaman genetik sudah cukup rendah, tetapi dari dendogram ini terlihat masih ada individu-individu yang terpisah cukup jauh dari kelompoknya misalnya 'Pena Molo', sehingga perbaikan sifat melalui seleksi masih dapat dilakukan dengan sangat selektif.

Keanekaragaman genetik suatu populasi dapat terjadi karena adanya interaksi dari beberapa faktor seperti mutasi, migrasi, rekombinasi, seleksi, dan hanyutan gen (genetic drift). Mutasi, migrasi, dan rekombinasi gen akan memperkaya keragaman dalam populasi alami, sedangkan seleksi dan hanyutan genetik cenderung mengurangi variasi (Mangoendidjojo, 2003).

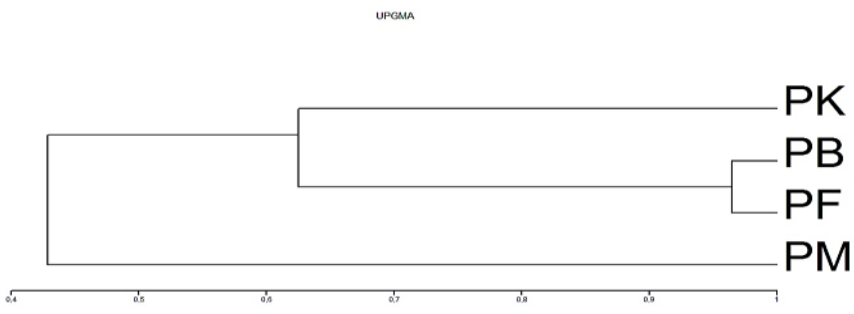

Gambar 1. Dendogram berdasarkan karakter fenotip 4 varietas jagung lokal PM: Pena Molo, PF: Pena Fatu, PB: Pena Boto, PK: Pena Kikis.

Nilai similaritas yang rendah pada karakter fenotip dalam penelitian ini disebabkan karena karakter fenotip yang diamati sangat sedikit atau kurang dari standar. Selain itu karakter fenotip yang digunakan untuk diagram fenetik hanya terdiri dari karakter kuantitatif dan tidak terdapat karakter kualitatif Karakter kuantitatif kurang stabil yaitu sering dipengaruhi oleh faktor lingkungan sehingga pengelompokkan pada diagram fenetik menunjukkan tingkat similaritas yang rendah.

\section{Simpulan}

Pengamatan terhadap 14 karakter fenotip menunjukkan keragaman pada 9 karakter fenotip yaitu tinggi tanaman, tinggi letak tongkol, jumlah daun, panjang daun, lebar daun, diameter batang, jumlah percabangan malai, berat tongkol, dan jumlah biji per baris. Jarak genetik individu-individu dalam populasi Varietas jagung lokal cukup dekat artinya keragaman genetik masih rendah dan masih dapat dilakukan dengan sangat selektif.

\section{Pustaka}

Amzeri, A., Indradewa, D., Daryono, B.S. \& Rachmawati, D. 2011. Kekerabatan Jagung (Zea mays L.) Lokal Madura Berdasarkan Karakter Morfologi dan Penanda RAPD. Biota, 16: 227-235.

Badan Pusat Statistik Kabupaten Timor Tengah Utara 2013. Luas Panen Produktivitas dan Produksi Jagung Menurut Kecamatan di Kabupaten TTU. Kefamenanu.

Fatmawati, Y., Purwantoro, A. \& Basunanda, P. 2017. Keragaman Morfolog dan Molekuler Empat Kelompok Kultivar Jagung (Zea mays L.). Vegetalika, 6(3): 50-64.

IBPGR, C. 1991. Descriptors for Maize. International Maize and Wheat Improvement Center, Mexico City. International Board for Plant Genetic Resources, Rome.

Maemunah, M. \& Yusran, Y. 2011. Karakterisasi Morfologi Varietas Jagung Ketan Di Kecamatan Ampana Tete Kabupaten Tojo Una-una. MEDIA LITBANG SULTENG, 3(2).

Mangoendidjojo 2003. Dasar-dasar Pemuliaan tanaman. Yogyakarta: Kanisius.

Mustofa, Z., Budiarsa, I.M. \& Samdas, G.B.N. 2013. Variasi Genetik Jagung (Zea mays L.) Berdasarkan Karakter Fenotipik Tongkol Jagung yang Dibudidaya di Desa Jono Oge Genetic Variation of Maize (Zea mays L.) Cultivated in Village of Jono Oge Based on the Cob Phenotypic Characters. EJIP BIOL, 2(3).

Pabendon, M.B., Azrai, M., Kasim, F. \& Mejaya, M.J. 2007. Prospek penggunaan markah molekuler dalam program pemuliaan jagung. Maros
(ID): Pusat Penelitian dan Pengembangan Tanaman Pangan, Balitsereal.

Rohlf, F. \& NTSYS-pc, N.T. 2000. Multivariate Analysis System, Version 2.10 e, Applied Biostatistics. Inc, New York.

Romesburg, C. 2004. Cluster Analysis for Researchers. Lulu.com.

Subekti, N.A., Syafruddin, E.R. \& Sunarti, S. 2007. Morfologi tanaman dan fase pertumbuhan jagung. Di dalam: Jagung, Teknik Produksi dan Pengembangan. Jakarta (ID): Pusat Penelitian dan Pengembangan Tanaman Pangan. 